А.П. Бурлака ${ }^{1}$, I.І. Ганусевич ${ }^{1}$, I.М. Мотузюк ${ }^{3}$, О.І. Сидорчук ${ }^{3}$, С.В. Вірко ${ }^{2}$, В.А. Чернобай²

\title{
Молекулярний механізм формування мамографічної щільності тканини молочної залози
}

\author{
${ }^{1}$ Інститут експериментальної патологї̈, онкологї̈ і радіобіології ім. Р.С. Кавецького НАН Украӥни, Киӥв \\ ${ }^{2}$ Інститут фізики напівпровідників імені В. С. Лашкарьова НАН Украӥни, Київ \\ ${ }^{3}$ Національний медичний університет ім. О.О. Богомольця МОЗ Украӥни, Київ \\ Одержано: 10.07.2020 \\ Прийнято до друку: 22.07.2020 \\ DOI: 10.32471/clinicaloncology.2663-466X.37-1.27186
}

\begin{abstract}
Мамографічна щільність тканини (МщТ) - це ступінь розповсюдження радіощільної фіброгландулярної тканини у молочній залозі (М3). Мамограма демонструє наявність двох складових компонентів у МЗ - фіброгландулярної та жирової тканини, які мають різний коефіцієнт послаблення рентгенівських променів. Щільність тканини МЗ може бути фактором ризику розвитку раку МЗ. Мета дослідження. Виявити зміни у редокс-стані тканини МЗ хворих у пре- та постменопаузальному віці, у яких реєструється МЩТ та ожиріння. Матеріали і методи дослідження. Дослідження проведені на біопсійному матеріалі 46 хворих пре- (1-ша група) та постменопаузального віку (2-га група) з ожирінням. Мамограми сканували, після чого у програмі ArchiCAD Graphisoft 14 підраховували площу щільної ділянки та класифікували за системою B1-RADS відповідно до відсотка мамографічної щільності (МЩ). За результатами наших досліджень та досліджень інших авторів, у хворих із МЩТ грудей 75\% ризик виникнення раку М3 у 4-6 разів вищий, ніж у жінок з низькою або відсутньою Мщт МЗ. У жінок як в період пременопаузи, так і постменопаузи рівні генерування супероксидних радикалів у МЗ з МЩ значно зростають порівняно $з$ контролем. Індекс маси тіла обернено корелює з МЩ, оскільки більша маса тіла пов'язана з більшою площею нещільної тканини мамограми, що відображає більшу кількість жирової тканини у МЗ. У хворих з Мщ МЗ у пре- та постменопаузальному віці рівні 8-охо-dG у сечі є вищими від контрольних значень та визначаються в межах 1,89-2,15 нмоль/кг маси тіла та 2,58-3,0 нмоль/кг маси тіла відповідно. Крім того, рівні 8-oxodG у хворих у постменопаузальному віці були вищими, порівняно з пацієнтами в період пременопаузи. Виявлено достовірну асоційованість високих рівнів активності матриксної металопротеїнази-2 з високою МЩ. У групі пацієнток, МЩ яких становила $38 \pm 7,7 \%$, рівні активності матриксної метало-

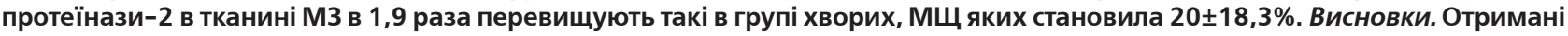
нами результати дозволяють припустити, що утворення МщТ у МЗ можуть спричиняти ендогенні процеси, які призводять до пошкодження ДНК та посилення проліферації клітин. До них слід віднести всі редокс-залежні процеси, які протікають у мітохондріях та імунних клітинах, при функціонуванні яких можуть генеруватися супероксидні радикали, зростати активність клітин з NO-синтазною активністю, утворюватися продукти перекисного окиснення ліпідів та білків, активуватися редокс-залежні процеси деградації позаклітинного матриксу (активація матриксної металопротеїнази), зростати метаболізм гормонів через цитохром P450, наприклад CYP 1A2, який метаболізує естрадіол до 2-гідрокси- та 4-гідрокси-метаболітів, останній з яких $\epsilon$ естрогенним і канцерогенним. Катехолестрогени можуть спричиняти канцерогенез, стаючи джерелом реактивних форм кисню та вступаючи в окислювально-відновний цикл (тобто повторні цикли окислення та відновлення з утворенням 3, 4-семихінонів та 3, 4-хінонів, які відрізняються високою реакційною здатністю, можуть зв'язуватися з ДНК та створювати депуринуючі аддукти, які індукують мутації генів і можуть призвести до фіброзного ремоделювання жирової тканини та ініціації проліферації.
\end{abstract}

Ключові слова: формування мамографічно щільної тканини молочної залози; 8-оксогуанін; супероксидні радикали; оксид азоту; цитохром Р450; ММП-2; ММП-9.

\section{ВстУП}

Мамографічна щільність тканини (МЩТ) - це ступінь розповсюдження радіощільної фіброгландулярної тканини у молочній залозі (М3). Мамограма демонструє наявність двох складових компонентів у М3 - фіброгландулярної та жирової тканини (ЖТ), які мають різний коефіцієнт послаблення рентгенівських променів. Тому щільність тканини М3 може бути фактором ризику розвитку раку МЗ (РМЗ) через ії маскуючий вплив при мамографічному обстеженні, а також є основним фактором ризику розвитку раку [1, 2]. Ожиріння, поширеність якого зростає в усьому світі, є ключовим фактором ризику розвитку та прогнозування РМЗ $[3,4]$. Це зазвичай пояснюється тим, що ЖТ набуває ендокринних функцій, а також тим, що у разі ожиріння відбувається фіброзне ремоделювання ЖТ. Тим не менш, точні механізми, за допомогою яких ЖТ може впливати на патогенез РМ3, залишаються в основному невизначеними. Відомо, що кожна клітина людини піддається оксидантній атаці зі швидкістю $1,5 \cdot 10^{5}$ впливів за день. Якщо з якихось причин вироблення супероксидних радикалів (СР) збільшується, то клітини переходять у стан, відомий як окисний стрес. Нерегульоване зростання внутрішньоклітинного рівня СР викликає окиснювання ліпідів, білків та ДНК, а за цих умов можуть відбуватися зміни щільності та жорсткості позаклітинного матриксу (ПМ) у тканині, які виявляють за допомогою мамографії і які викликають розвиток пухлин, їх прогресування та відповідь на терапію. У цьому процесі можуть брати участь матриксні металопротеїнази (ММП), які ремоделюють ПМ, а при порушенні балансу між активацією ММП та їх інгібіторами внаслідок змін їх редоксрегуляції, вони можуть відігравати вирішальну роль у формуванні МЩТ МЗ.

\section{МЕТА ДОСЛІДЖЕННЯ}

Метою дослідження є виявлення змін у редокс-стані тканини МЗ хворих у пре- та постменопаузальному віці, у яких реєструється МЩТ та ожиріння.

\section{МАТЕРІАЛ I МЕТОДИ ДОСЛІДЖЕННЯ}

Дослідження проведені на біопсійному матеріалі 46 хворих пре- (1-ша група) та постменопаузального віку (2-га група) з ожирінням. Мамограми сканували у програмі ArchiCAD Graphisoft 14, підраховували площу щільної ділянки та класифікували за системою B1-RADS відповідно до відсотка мамографічної щільності (МЩ). Ступінь МЩ можна виміряти і виразити у відсотках, визначивши частку від загальної площі 
М3, яка зайнята щільною тканиною. До дослідження залучали хворих II категорії у яких МЩ становила 25-50\%. Швидкість генерування СР та NO визначали методом електронного парамагнітного резонансу, відповідно до роботи [5], а швидкість окиснення ДНК визначали спектрофотометрично за методикою, наведеною в дослідженні [6]. Рівні низькоспінової форми цитохрому P450 (CYP 1A2) у гомогенаті тканини визначали методом електронного парамагнітного резонансу за температури рідкого азоту $\left(196^{\circ} \mathrm{C}\right)$ та спектрофотометрично. UV-Vis-спектри поглинання реєстрували при концентрації білка 0,5 нмоль у 1 мл 0,1 М фосфатного буферу (pH 76,0). Імуноблотинг проводили відповідно до протоколу з антитілами проти СYР 1А2, GAPDH (Santa Cruz Biotechnology, Santa Cruz, CA), активність ММП-2 та ММП-9 - за методикою, наведеною в роботі [7]. Наявність ожиріння у хворих визначали шляхом підрахунку індексу маси тіла (IMT). Дані представлені у вигляді середніх значень зі стандартним відхиленням ( $\pm \mathrm{SE})$.

\section{РЕЗУЛЬТАТИ ДОСЛІДЖЕНЬ}

МЩТ МЗ. У жінок з МЩТ МЗ виявляють різні категорії щільності. Вони описуються чотирма категоріями: I категорія - МЗ складається в основному з ЖТ, яка має дуже низьку щільність; II категорія - значна частина МЗ складається з ЖТ та кількох ділянок щільної залозистої та сполучної тканини; III категорія - більша частина МЗ заміщена залозистою та сполучною тканиною, а решту об'єму займає ЖТ; IV категорія - M3 майже повністю складається із залозистої та сполучної тканини з дуже високою щільністю. Результати досліджень МЩТ МЗ жінок представлені в таблиці. Детальний аналіз приведених у таблиці результатів буде зроблено нижче.

На рис. 1 представлено рівні МЩТ у МЗ хворих залежно від віку та менопаузального статусу.

Виявлено, що середній відсоток МЩТ МЗ знижувався з віком, як у жінок, у яких розвинувся РМЗ, так і у тих, хто не захворів, але в будь-якому віці відсоток щільної тканини у МЗ був вищим у тих пацієнток, у яких виник РМЗ. IMT позитивно асоціювався з ризиком РМЗ у жінок в період постменопаузи та негативно - у жінок, що знаходилися в періоді пременопаузи. За результатами наших досліджень та інших авторів, у хворих зі щільністю грудей $75 \%$ ризик виникнення РМ3 є в 4-6 разів вищим, ніж у жінок з низькою або відсутньою щільністю тканини М3 [1-4]. Таким чином, МЩТ $€$ незалежним фактором ризику розвитку РМЗ, маркером сприйнятливості до РМЗ та відображає тканинний склад М3, яка позитивно асоціюється 3 колагеновими, епітеліальними та неепітеліальними клітинами, а негативно - з ЖТ.

CP, IMT та МЩТ МЗ. Середній IМТ у хворих пременопаузального віку становив $25,9 \pm 6,5$ року, а у постменопаузальних пацієнтів - 26,5 $\pm 6,8$ року. У цих груп хворих МЩТ мала наступні значення: для 1-ї групи $-30,6 \pm 17,0$, для 2-ї $19,9 \pm 16,3$, а IMТ відповідно складав $25,9 \pm 6,5$ та $26,5 \pm 6,8$ року. Ожиріння сприймають як пошкоджуючий фактор, який погіршує якість життя через супутні ускладнення, включаючи цукровий діабет, серцево-судинні захворювання, рак, дисфункцію печінки, порушення функції нирок та безпліддя. Крім того, ожиріння - це складне порушення обміну речовин, що пов'язане з багатофакторними пошкодженнями, серед яких найважливішим є порушення редокс-стану

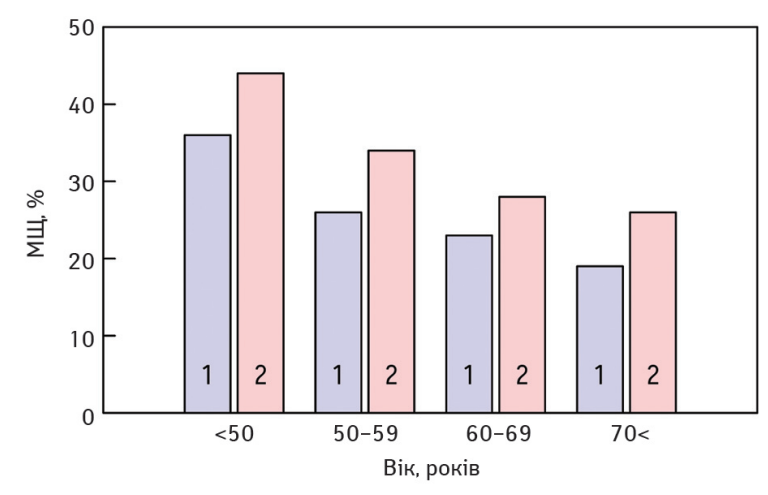

Рис. 1. Вік, МЩТ МЗ та захворюваність на РМЗ. 1 - середній відсоток щільної тканини у МЗ жінок, у яких не розвинувся РМЗ; 2 - середній відсоток щільної тканини у МЗ жінок у яких розвинувся РМЗ через $1-5$ років. Дані представлені, $\mathrm{p}<0,05$.

3 формуванням оксидативного стресу, який обумовлює виникнення супутніх ускладнень. Ожиріння саме по собі може викликати системний оксидативний стрес шляхом залучення різних біохімічних механізмів, зокрема генерування СР нікотинамідаденіндинуклеотидфосфат-оксидазою, порушення механізму окисного фосфорилювання та детоксикації $[8,9]$. Із представлених даних (див. таблицю) видно, що у жінок, як у період пременопаузи, так і постменопаузи рівні генерування СР у МЩТ МЗ підвищуються порівняно 3 контролем $(0,24 \pm 0,06$ нмоль/г сир. ткан. - хв.) до значень $1,13 \pm 0,15$ нмоль/г сир. ткан. • хв (1-ша група хворих) та 1,78 $\pm 0,1$ нмоль/г сир. ткан. • хв. (2-га група). У цих пацієнтів IMT обернено корелює з відсотком МЩ, оскільки більша маса тіла пов'язана з більшою площею нещільної тканини мамограми, що відображає більшу кількість ЖТ у МЗ.

Ожиріння, окиснення ДНК і МЩТ МЗ. У людей з ожирінням визначається широкий спектр пошкоджень ДНК, а саме: двониткові, однониткові розриви ланцюга та у 2 рази вищі рівні окиснення основ ДНК, ніж у осіб з нормальною масою тіла. Наявність ожиріння викликає хронічне перевантаження енергією, що призводить до підвищення рівнів СР та запалення. Нами встановлено, що джерела генерування СР у ЖТ можуть відрізнятися залежно від стадії ожиріння. На ранніх стадіях посилюється засвоєння мітохондріями адипоцитів глюкози та жирних кислот, відбувається поділ мітохондрій, мітохондріальне $\beta$-окислення вільних жирних кислот та збільшення генерування СР. 3 наростанням маси ЖТ активується нікотинамідаденіндинуклеотидфосфат-оксидаза нейтрофілів, генерування нею СР та інших прозапальних адипокінів. Прозапальні цитокіни індукують міграцію у ЖТ Т-лімфоцитів і макрофагів, що спричиняє розвиток хронічного запалення через посилене генерування СР нікотинамідаденіндинуклеотидфосфат-оксидазою-2 цих клітин.

На рис. 2 представлені дані щодо рівнів 8-оксо-2'-дезоксигуанозину (8-oxо-dG) у МЩТ хворих 1-ї та 2-ї груп. Ми встановили, що за умов хронічного запа-

Таблиця. МЩТ та ішні фактори ризику розвитку РМЗ

\begin{tabular}{|c|c|c|c|}
\hline Фактор ризику & Пременопауза & Постменопауза & $\begin{array}{c}\text { Контрольні } \\
\text { значенняя }\end{array}$ \\
\hline Вік (роки) & $45,4 \pm 3,1$ & $56,3 \pm 4,6$ & \\
\hline Маса тіла (кг) & $69,1 \pm 13,3$ & $72,5 \pm 16,6$ & \\
\hline IMT $\left(\mathrm{Kr} / \mathrm{M}^{2}\right)$ & $25,9 \pm 6,5$ & $26,5 \pm 6,8$ & \\
\hline МЩТ (\%) & $30,6 \pm 17,0$ & $19,9 \pm 16,3$ & \\
\hline Активність СҮР 1 А2 (відн. од.) & $1,89 \pm 0,12$ & $2,03 \pm 0,09$ & $0,81 \pm 0,07$ \\
\hline Рівень $\mathrm{O}_{2} \cdot($ нмоль $/($ г тканини) · хв) & $1,13 \pm 0,15$ & $1,78 \pm 0,19$ & $0,24 \pm 0,06$ \\
\hline Рівень 8-охо-G (нмоль/(кг маси тіла)· доба) & $2,02 \pm 0,13$ & $2,79 \pm 0,21$ & $0,2 \pm 0,04$ \\
\hline Активність iNOS (нмоль/(105 клітин)· хв) & $2,03 \pm 0,12$ & $2,47 \pm 0,11$ & $1,45 \pm 0,09$ \\
\hline Рівень ММП-2 (ум. од.) & $6,8 \pm 2,2$ & $3,1 \pm 1,17$ & $0,20 \pm 0,03$ \\
\hline Рівень ММП-9 (ум. од.) & $3,5 \pm 1,6$ & $4,6 \pm 2,7$ & $0,18 \pm 0,08$ \\
\hline
\end{tabular}


лення, пов’язаного з ожирінням, підвищуються рівень маркера окиснення ДНК СР, генерованими активованими макрофагами у нецільових тканинах, віддалених від місця запалення, оскільки недетоксиковані цитокіни, циркулюючи у різних ділянках організму, активують макрофаги, які у віддалених тканинах починають продукувати прозапальні молекули, такі як СP та NO.

СР та їх метаболіти - радикальні форми кисню (РФК) здійснюють істотний внесок у розвиток раку, частково через їх здатність реагувати з ДНК. Вони можуть пошкоджувати піримідини, пурини та хроматинові білки, що призводить до утворення модифікованих основ, геномної нестабільності та зміни в експресії генів. 8-охо-dG - специфічний маркер 20-дезоксигуанозину, який утворюється в ДНК після атаки РФК на цю молекулу. У даному дослідженні ми проаналізували рівень 8-охо-dG у сечі хворих з МЩТ М3 залежно від їх менопаузального статусу та IMT. Представлені на рис. 2 результати досліджень свідчать про те, що у хворих з МЩТ у пре- та постменопаузальному віці рівні 8-охо-dG у сечі обох груп є вищими від контрольних значень та визначалися в межах 1,89-2,15 нмоль/кг маси тіла/добу у хворих 1-ї групи та 2,58-3,0 нмоль/кг маси тіла/добу у пацієнтів 2-ї групи. Крім того, рівні 8-охо-dG у хворих постменопаузального віку були вищими, ніж у тих, хто знаходився в періоді пременопаузи. Слід зазначити, що високі рівні маркера окиснення ДНК були характерною ознакою для хворих, у яких виявляли високі рівні МЩТ М3 і в яких з часом виник РМЗ. Виявлено кореляцію між ІМТ та окисним пошкодженням ДНК, оскільки ЖТ здійснює свій внесок у підвищення рівня СР. У цьому дослідженні ми вперше демонструємо негативний вплив утворення 8-охо-dG на перебіг МЩТ М3 та те, що високі рівні 8-охо-dG характерні для більш агресивного перебігу захворювання, оскільки при утворенні 8-охо-dG у ДНК відбуваються трансверсійні мутації GC-TA під час реплікації ДНК i, таким чином, вони стають мутагенними. Учені $[6,10]$ у своїх дослідженнях виявили, що у пацієнтів з карциномами М3 та хворих на метастатичний колоректальний рак рівень 8-охо-dG у 8-17 разів перевищував показники, характерні для здорової тканини МЗ та кишечнику. Таким чином, визначення рівнів 8-охо-dG може бути використано в якості прогностичного фактора ризику розвитку РМЗ у разі виявлення МЩТ у М3.

Активність цитохрому P450 1А2 (CYP 1A2) та МЩТ М3. Нами було виявлено високу активність цитохрому P450 1A2 (СYP 1А2) у МЩТ М3 обох групах хворих. Результати цих досліджень представлені на рис.3. Активність CYP 1A2 у групі хворих пременопаузального віку становила $1,89 \pm 0,12$, а у пацієнтів 3 постменопаузальним статусом цей

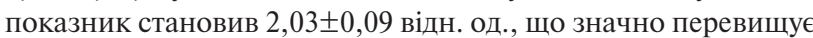
значення, які характеризують умовно здорову М3 $(0,81 \pm 0,07)$.

Метаболізм естрогенів CYP 1A2 та підвищення рівнів катехолестрогену може бути причиною формування

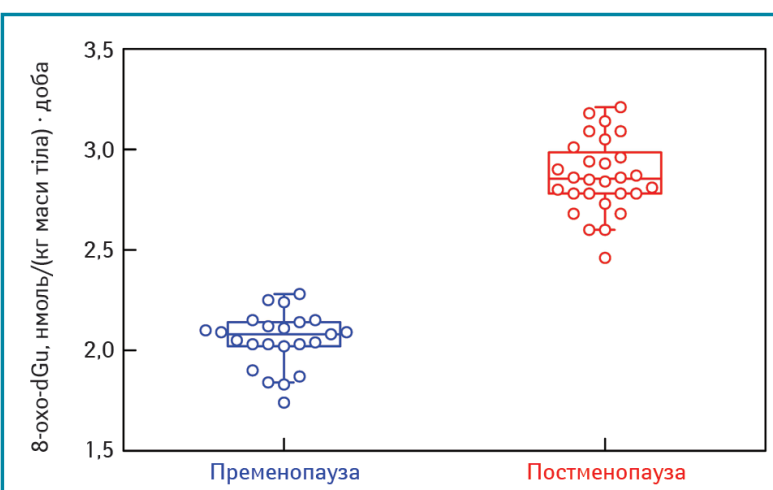

Рис. 2. Рівень 8-охо-dG залежно від менопаузального статусу хворих
МЩТ М3. СҮР 1А2 головним чином відповідає за метаболізм 17ß-естрадіолу Е2) після початкової його конверсії в естрон (Е1). У людини до 50\% естрогенів піддаються 2-гідроксилюванню, а 5-8\% - 4-гідроксилюванню. Ми вважаємо, що катехолестрогени можуть потенційно впливати на рівні щільності тканини МЗ через оксидативні механізми. 2-гідроксиестрогени є неестрогеноактивними і нетуморогенними. На відміну від 2-гідроксиестрогенів, 4-гідроксиестрогени проявляють естрогенну активність та є канцерогенними у зв'язку зі здатністю генерувати генотоксичні та цитотоксичні РФК, Які можуть пошкоджувати ДНК, спричиняти перекисне окиснення ліпідів з утворенням мутагенного малонового діальдегіду, що є фактором ризику формування МЩ.

Активність ММП та МЩТ МЗ. Дані, кількість яких збільшується, підтверджують уявлення про те, що змінена регуляція ПМ спричиняє неопластичне прогресування, а порушення в структурі ПМ можуть передувати епітеліальним змінам. ММП, цинк-залежні ендопептидази, що беруть участь у ремоделюванні ПМ, впливають на всі етапи прогресування пухлини, включаючи міграцію, ангіогенез та метастатичне ураження. Порушення балансу між ММП та їх тканинними інгібіторами пов'язане з прогресуванням раку [11]. Ми дослідили активність ММП-2 і ММП-9 у МЩТ зазначених груп хворих. Результати цих досліджень представлені на рис.4.

Виявлено, що для тканини МЗ жінок пременопаузального віку характерні достовірно більш ніж у 2 рази вищі показники активності ММП-2 порівняно з тканиною МЗ пацієнток в постменопаузальний період. Шодо активності ММП-9 суттєвої різниці в цих групах пацієнток не виявлено (див. таблицю). 3 таблиці видно, шо показники активності желатиназ можуть бути пов'язані з рівнями МЩТ МЗ, а аналіз отриманих даних продемонстрував достовірну асоційованість високих рівнів активності ММП-2 з високою МЩТ (рис. 4). Для цього хворих розподілили на 2 групи - з умовно низькою та умовно високою МЩТ М3, де в 2-й групі ці показники удвічі перевищували такі в 1-й групі. Показано, що в групі пацієнток, МЩТ яких становила $38 \pm 7,7 \%$, рівні активності ММП-2 в тканині М3, в 1,9 раза перевищують такі в групі хворих, МЩТ яких становила $20 \pm 18,3 \%$. Порушення нормальної редокс-залежної мережі міжклітинної сигналізації та зміни клітинно-молекулярного мікрооточення можуть створити умови, що спричиняють ріст пухлини. У прозапальному мікрооточенні зі зміною редокс-стану в бік окиснення стромальні фібробласти можуть регулювати активність ММП та інші ферменти, які відповідають за деструкцію ПМ. Ці порушення стимулюють інфільтрацію тканини імунними клітинами, продукування РФК, шо в кінцевому підсумку спричиняє аномальну проліферацію та інвазію [12]. Парадоксальним є наступний факт: з віком у людини відсоток МЩТ у МЗ демонструє тенденцію до зниження, а частота РМЗ в цілому підвищується, це можна пояснити на основі моделі, запропонованої Пайком. У ній

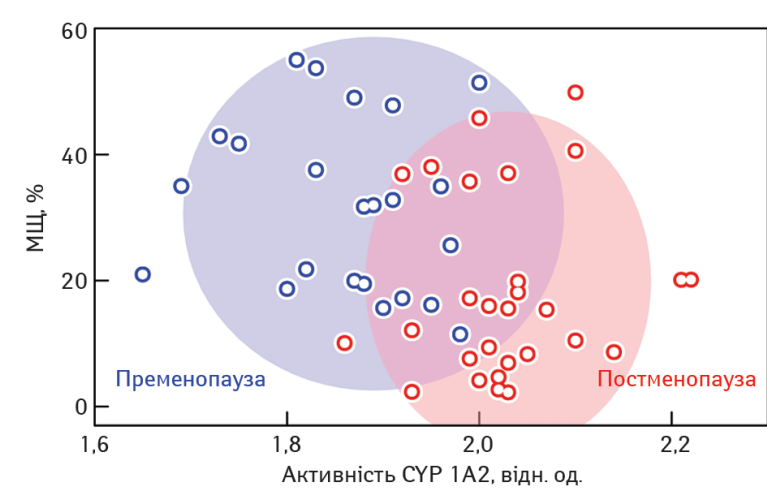

Рис. 3. Розподіл хворих залежно від відсотку МщТ МЗ та активності CYP 1A2 
стверджується, що реальний вік тканини МЗ є наслідком накопиченого протягом життя впливу гормонів, пошкоджувальних факторів, а не хронологічного віку. Особливо це стосується РМ3, пов'язаного зі стійким впливом гормонів (наприклад естрогену в матерів першої вікової групи в старшому віці), у яких зазвичай відмічають більш високий ступінь МЩТ [13]. Важливою особливістю МЩТ, порівняно з іншими відомими факторами ризику, $€$ те, що вона може змінюватися, і критична роль у цих тканинних перебудовах належить редокс-залежим процесам регулювання ММП [14]. Така пластичність може стати основою розробки підходів до зниження відсотка МЩТ МЗ через вплив на активність ММП в стратегіях запобігання виникненню раку.

Оксид азоту та МЩТ МЗ. Раніше [15] нами було показано, що NO-генеруюча активність iNOS нейтрофілів підвищується залежно від ступеня диференціювання пухлин, а рівні біосинтезу NO були вищими у зразках пухлин РМЗ III стадії порівняно з ІІ стадією. Ми припускаємо, що у стромальних клітинах, пухлиноасоційованих макрофагах та у пухлинних клітинах експресується не тільки iNOS, а й інші NO-синтази. NO - це вільний радикал, високореактивна молекула в біологічних системах, яка здатна взаємодіяти з клітинами та іншими вільними радикалами, зокрема 3 молекулярним киснем та іонами металів. Біологічні ефекти NO можуть бути опосередковані продуктами метаболізму NO (нітрити та нітрати, S-нітрозо-тіоли та пероксинітрат), i, як вважається, ці метаболіти відіграють ключову роль в опосередкуванні багатьох NO-асоційованих генотоксичних ефектів, які включають пошкодження ДНК шляхом розриву ниток або модифікацію ДНК.

При дослідженні NO-генеруючої активності нейтрофілів у хворих з МЩТ у пре- та постменопаузальному віці та надмірною масою тіла виявлено підвищення активності іNOS (див. таблицю). У хворих 1-ї групи iNOS продукувала оксид азоту зі швидкістю $2,03 \pm 0,12$ нмоль/105клітин • хв., а у хворих 2-ї гру-

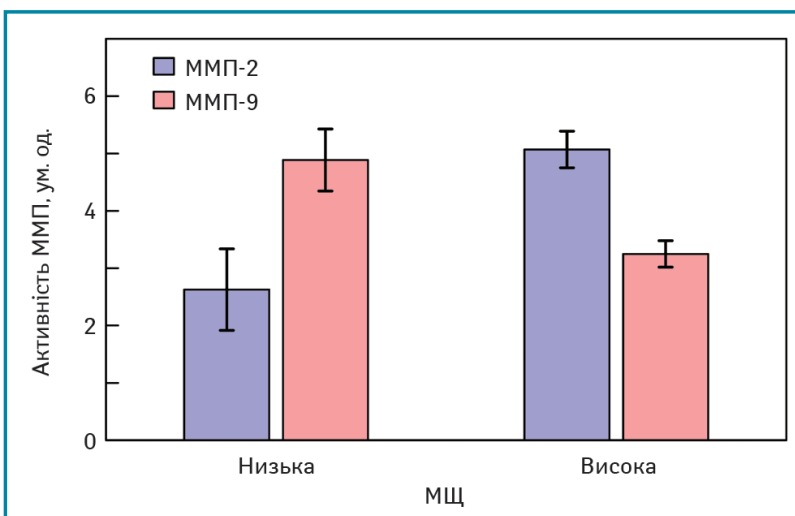

Рис. 4. Активність желатиназ (ММП-2 та -9) у тканині

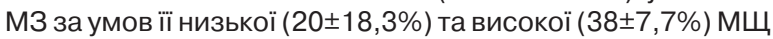

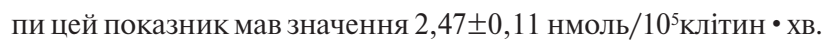
Підвищення активності нейтрофілів, генерування ними неконтрольованих рівнів NO можуть проявляти пропухлинну активність у тканинах. NO може сприяти ангіогенезу за рахунок регулювання фактора росту ендотелію судин (vascular endothelial growth factor - VEGF) та модулювання механізму відновлення пухлинної ДНК шляхом регулювання р53, полі(АДФ-рибози)-полімерази(Poly (ADP-ribose) polymerase PARP) та ДНК-залежної протеїнкінази (DNA-dependent protein kinase - DNA-PKcs) [16, 17]. Усе викладене вище представлено у вигляді схеми на рис. 5.

Різноманітні ендогенні та екзогенні фактори (генетичні та епігенетичні фактори, хронічне запалення, старіння, спосіб життя, дієта) можуть порушувати редокс-гомеостаз шляхом зміщення рівноваги між активуючими та деактивуючими ферментами, що спричиняє нерегульоване генерування РФК, утворенням метаболітів гормонів (хінонів), аддуктів естроген-ДНК та окисних мутацій ДНК у клітинах М3. Перший важливий фактор, пов'язаний 3 канцерогенезом у М3, є процес підвищення активності цитохрому P450, зокрема CYP 1A2. Другим значущим фактором у цьому ланцюгу подій, який порушує метаболізм естрогенів, є дерегуляція сульфатази, що перетворює надмірно накопичений естрон сульфат на Е1 (естрон). До третього критичного фактору, який бере участь у порушенні гомеостазу естрогенів, $є$ активація СҮР 1B1, який спричиняє вироблення високих рівнів 4-ОН-Е1(естрон) (Е2-естрадіолу) із Е1. Високі рівні 4-ОН-Е1 (Е2) можуть призвести до підвищення рівня канцерогенних Е1 (E2)-3,4хінонів, здатних генерувати окисні пошкодження гуаніну у ДНК та інші точкові мутації, які можуть ініціювати РМЗ та інші поширені гормонозалежні типи раку.

\section{висновки}

Отримані нами результати дозволяють припустити, що утворення МЩТ у МЗ можуть спричиняти ендогенні процеси, які здатні призвести до пошкодження ДНК та посилення проліферації клітин. До них слід віднести: усі редокс-залежні процеси, які протікають у мітохондріях, імунних клітинах, при функціонуванні яких можуть генеруватися СР, підвищуватися активність клітин з NO-синтазними властивостями, утворюватися продукти перекисного окиснення ліпідів та білків, активуватися редокс-залежні процеси деградації ПМ (активація ММП), зростати метаболізм гормонів цитохромом Р450, наприклад СҮР 1А2, який метаболізує естрадіол до 2-гідрокси та 4-гідрокси метаболітів, останній з яких є естрогенним і канцерогенним. Катехолестрогени можуть спричиняти канцерогенез, стаючи джерелом РФК та вступаючи в окислювально-відновний цикл (тобто повторні цикли окислення та відновлення з утворенням 3, 4-семихінонів та 3, 4-хінонів, які відрізняються високою реакційною здатністю і можуть зв'язуватися з ДНК та створювати депуринуючі аддукти, які індукують мутації генів і можуть призвести до фіброзного ремоделювання ЖТ та ініціації проліферації.

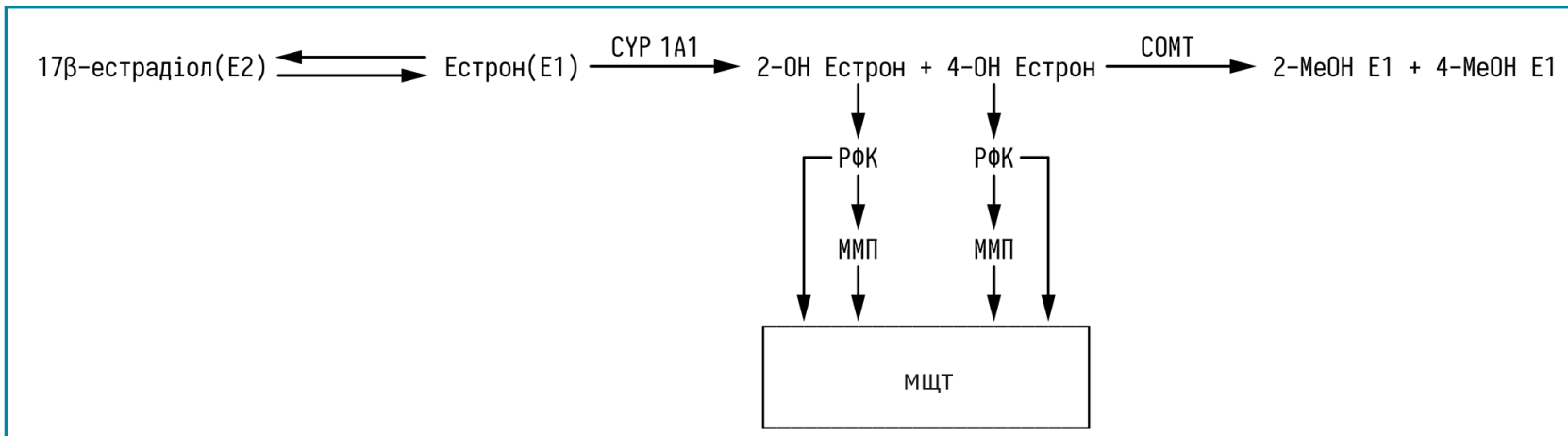

Рис. 5. Схема редокс-залежних механізмів формування МЩТ у тканині МЗ 


\section{СПИСОК ВИКОРИСТАНОÏ ЛІТЕРАТУРИ}

1. Чешук, В. Є. (2014). Підвищена мамографічна щільність як фактор ризику розвитку раку молочної залози. Онкологія, 16(1), 13-16.

2. Phoebe, E. (2015). Mammographic Breast Density: Impact on Breast Cancer Risk and Implications for Screening. RadioGraphics, 35, 302-331. doi.org/10.1148/rg.352140106.

3. Simpson, E. R., Brown, K. A. (2013). View More Obesity and breast cancer: role of inflammation and aromatase. Journal of Molecular Endocrinology, 51, 5159. doi: 10.1530/JME-13-0217.

4. Seo, B. R., Bhardwaj, P., Choi, S., Gonzalez, J., Eguiluz, R. C., Wang, K., Fischbach, C. (2015). Obesity-dependent changes in interstitial ECM mechanics promote breast tumorigenesis. Science Translational Medicine, 7(301), 301-130. doi: 10.1126/scitranslmed.3010467.

5. Burlaka, A. P., Ganusevich, I. I., Vovk, A. V., Burlaka, A. A., Gafurov, M. R., \& Lukin, S. N. (2020). Redox state of adipose tissue for patients with gastric cancer and its connection with the body mass index and distance from the tumor. Obesity Research \& Clinical Practice, 14(1), 34-38. doi.org/10.1016/j.orcp.2019.10.003.

6. Burlaka, A., Rudiuk, T., Burlaka, A., \& Kolesnik, O. (2019). 8-hydroxydeoxyguanosine as an independent prognostic factor in patients with metastatic colorectal cancer. Archives of the Balkan Medical Union, 54(3), 445-454. doi: 10.31688/ABMU.2019.54.3.07.

7. Burlaka, A. P., Ganusevich, I. I., Gafurov, M. R., Lukin, S. M., \& Sidorik, E. P. (2016). Stomach Cancer: Interconnection between the Redox State, Activity of MMP-2, MMP-9 and Stage of Tumor Growth. Cancer Microenviron, 9(1), 27-32. doi: 10.1007/s12307-016-0182-5.

8. Lee, K., Kruper, L., Dieli-Conwright, C. M., \& Mortimer, J. E. (2019). The Impact of Obesity on Breast Cancer Diagnosis and Treatment. Current Oncology Reports, 21(5), 41. doi: 10.1007/s11912-019-0787-1.

9. Picon-Ruiz, M., Morata-Tarifa, C., Valle-Goffin, J. J., Friedman, E. R., \& Slingerland, J. M. (2017). Obesity and adverse breast cancer risk and outcome: Mechanistic insights and strategies for intervention. A Cancer Journal for Clinicians, 67(5), 378-397. doi: 10.3322/caac.21405

10. Matsui, A., Ikeda, T., Enomoto, K., Hosoda, K., Nakashima, H., Omae, K., ... Kitajima, M. (2000). Increased formation of oxidative DNA damage, 8-hydroxy2-deoxyguanosine, in human breast cancer tissue and its relationship to GSTP1 and COMT genotypes. Cancer Letters, 51, 87-95. doi: 10.1016/s0304-3835(99)00424-3.

11. Steude, J. S., Maskarinec, G., Erber, E., Verheus, M., Hernandez, B. Y., Killeen, J., \& Cline J. M. (2010). Mammographic Density and Matrix Metalloproteinases in Breast Tissue. Cancer Microenviron, 3(1), 57-65. doi: 10.1007/s12307-009-0031-x

12. Walker, C., Mojares, E., \& Del Rio Hernandez, A. (2018). Role of Extracellular Matrix in Development and Cancer Progression. International Journal of Molecular Sciences, 19, 3028. doi: 10.3390/ijms19103028.

13. Greendale, G. A., Reboussin, B. A., Slone, S., Wasilauskas, C., Pike, M. C., \& Ursin, G. (2003). Postmenopausal hormone therapy and change in mammographic density. Journal of the National Cancer Institute, 95, 30-37. doi: 10.1093/jnci/95.1.30.

14. Fernández-Nogueira, P., Mancino, M., Fuster, G., Bragado, P., Puig, M. P. Gascón, P., ... Carbó, N. (2020). Breast Mammographic Density: Stromal Implications on Breast Cancer Detection and Therapy. Journal of Clinical Medicine, 9(3), 776. doi.org/10.3390/jcm9030776.

15. Burlaka, A. P., Ganusevych, I. I, Vovk, A. V., \& Lukin, S. M. (2017). Protumor effects of nitric oxide and superoxide radicals in adipose tissue of patients with colorectal and stomach cancer. International Journal of Medicine and Medical Research, 5(1), 26-32. doi: 10.11603/ijmmr.2413-6077.2019.1.9819.

16. Boyd, N. F., Martin, L. J., Bronskill, M., Yaffe, M., Duric, N., \& Minkin, S. (2010). Breast Tissue Composition and Susceptibility to Breast Cancer. Journal of the National Cancer Institute, 102, 1224-1237. doi: 10.1093/jnci/djq239.

17. Sarmiento-Salinas, F. L., Delgado-Magallón, A., Benito Montes-Alvarado, J., Ramírez-Ramírez, D., Carlos Flores-Alonso, J., Cortés-Hernández, P., ... Maycotte, P. (2019). Breast Cancer Subtypes Present a Differential Production of Reactive Oxygen Species (ROS) and Susceptibility to Antioxidant Treatment. Frontiers in Oncology, 9, 480. doi: 10.3389/fonc.2019.00480.

\section{Молекулярный механизм формирования}

маммографической плотности ткани молочной железы.

А.П. Бурлака ${ }^{1}$, И.И. Ганусевич ${ }^{1}$, И.М. Мотузюк ${ }^{3}$, О.И. Сидорчук ${ }^{3}$,

С.В. Вирко ${ }^{2}$ В.А. Чернобай

Институт экспериментальной патологии, онкологии и радиобиологии им. Р.Е. Кавецкого НАН Украины, Киев, ${ }^{2}$ Институт физики полупроводников им. В.Е. Лашкарева НАН Украины, Киев

${ }^{3}$ Национальный медицинский университет им. А.А. Богомольца МОЗ Украины, Киев

Резюме. Маммографическая плотность ткани (МПТ) - это степень распространения радиоплотной фиброгландулярной ткани в молочной железе (МЖ). Маммограмма демонстрирует наличие двух составляющих компонентов у МЖ - фиброгландулярной и жировой ткани, которые имеют разный коэффициент ослабления рентгеновских лучей. Плотность ткани МЖ может быть фактором риска развития рака МЖ. Цель исследования. Выявить изменения в редокс-состоянии ткани МЖ больных в пре- и постменопаузальном возрасте, у которых регистрируется МПТ и ожирение. Материалы и методы. Исследования проведены на биопсийном материале 46 больных пре- (1-я группа) и постменопаузального возраста (2-я группа) с ожирением. Маммограммы сканировали, после чего в программе ArchiCAD Graphisoft 14 подсчитывали площадь плотного участка и классифицировали по системе B1-RADS согласно проценту маммографической плотности (МП). По результатам наших исследований и исследований других авторов, у больных с МПТ груди 75\% риск возникновения рака МЖ в 4-6 раз выше, чем у женщин с низкой или отсутствующей МПТ МЖ. У женщин как в период пременопаузы, так и постменопаузы уровни генерирования супероксидных радикалов в МЖ с МП значительно повышаются по сравнению с контролем. Индекс массы тела обратно коррелирует с МП, поскольку большая масса тела связана с большей площадью неплотной ткани маммограммы, что отражает большее количество жировой ткани в МЖ. У больных с МП МЖ в пре- и постменопаузальном возрасте уровни 8-охо-dG в моче выше контрольных значений и определяются в пределах 1,89-2,15 нмоль/кг массы тела и 2,58-3,0 нмоль/кг масы тела соответственно. Кроме того, уровни 8-oxo-dG у больных в постменопаузальном возрасте были выше по сравнению с пациентами в период пременопаузы. Выявлено достоверную ассоциированность высоких уровней активности матриксной металлопротеиназы-2 с высокой МП. В группе пациенток, МП которых составила $38 \pm 7,7 \%$, уровни активности матриксной металлопротеиназы-2 в ткани МЖ в 1,9 раза превышают таковые в группе больных, МП которых составляла $20 \pm 18,3 \%$. Выводы. Полученные нами результаты позволяют предположить, что образование МПТ в МЖ могут вызвать эндогенные процессы, которые приводят к повреждению ДНК и усилению пролиферации клеток. К ним следует отнести все редокс-зависимые процессы, которые протекают в митохондриях и иммунных клетках, при функционировании которых могут генерироваться супероксидные радикалы, повышаться активность клеток с NO-синтазной активностью, образовываться продукты перекисного окисления липидов и белков, активироваться редокс-зависимые процессы деградации внеклеточного матрикса (активация матриксной металлопротеиназы), повышаться метаболизм гормонов через цитохром Р450, например СYР 1А2, который метаболизирует эстрадиол до 2-гидрокси и 4-гидрокси-метаболитов, последний из которых является эстрогенным и канцерогенным. Катехолэстрогены могут вызывать канцерогенез, становясь источником реактивных форм кислорода и вступая в окислительно-восстановительный цикл (то есть повторные циклы окисления и восстановления с образованием 3, 4-семихинонов и 3, 4-хинонов, которые отличаются высокой реакционной способностью, могут связываться с ДНК и создавать депуринирующие аддукты, которые индуцируют мутации генов и могут привести к фиброзному ремоделированию жировой ткани и инициации пролиферации.

Ключевые слова: формирование маммографически плотной ткани молочной железы; 8-оксогуанин; супероксидные радикалы; оксид азота, цитохром Р450; ММП-2; ММП-9.

Molecular mechanism of mammographic density formation of the breast tissue

A.P. Burlaka', I.I. Ganusevich', I.N. Motuziuk ${ }^{3}$, O.I. Sydorchuk ${ }^{3}$,

S.V. Virko ${ }^{2}$, V.A. Chernobai ${ }^{2}$

${ }^{1}$ R.E. Kavetsky Institute of Experimental Pathology, Oncology and Radiobiology, NAS of Ukraine, Kyiv ${ }^{2}$ V.E. Lashkaryov Institute of Semiconductor Physics, NAS of Ukraine, Kyiv

${ }^{3}$ O. O. Bogomolets National Medical University, Ministry of Health of Ukraine, Kyiv

Introduction. Mammographic tissue density (MTD) is the extent to which radiodense fibroglandular tissue is spread in the mammary gland (MG). The mammogram demonstrates presence of two constituent components in the breast - fibroglandular and adipose tissues, which have different X-ray attenuation coefficients. The density of breast tissue can be a risk factor for breast cancer. Purpose of the study. To identify changes in the redox state of breast tissue in pre- and postmenopausal patients, in whom mammographic tissue density and obesity are also recorded. Materials and methods. The studies were carried out on biopsy material from 46 pre- (group 1) and postmenopausal (group 2) obese patients. Mammograms were 
scanned, the area of the dense sites was calculated in the ArchiCAD Graphisoft 14 program and classified according to the B1-RADS system according to the percentage of mammographic density (MD). Research results. It was revealed that the average percentage of MTD in the MG decreased with age - both in women who developed breast cancer (BC) and those who did not get sick - but at any age, the percentage of dense tissue in the breast was higher in women who developed breast cancer. Body mass index was positively associated with the risk of breast cancer in postmenopausal women and negatively in premenopausal women. According to the results of our studies and studies of other authors, in patients with a breast density of $75 \%$, the risk of breast cancer is $4-6$ times higher than in women with low or no MD of MG. In both premenopausal and postmenopausal women, the level of superoxide radicals generation in the MG with MD significantly increases compared to controls. Body mass index is inversely correlated with the percentage of mammographic density, since more weight is associated with a larger area of loose mammogram tissue, which reflects more AT in the MG. In patients with MD MG in pre- and postmenopausal age, the levels of 8-oxodG in the urine are higher than the control values and are determined in the range of 1.89-2.15 nmol / $\mathrm{kg}$ body weight and 2.58-3.0 $\mathrm{nmol} / \mathrm{kg}$ body weight respectively. In addition, the levels of 8-oxodG in postmenopausal patients were higher than in those who were premenopausal. A significant association of high levels of matrix metalloproteinase-2 activity with high MD was revealed. In the group of patients, whose MD was $38 \pm 7.7 \%$, the levels of matrix metalloproteinase-2 activity in the MG tissue were 1.9 times higher than those in the group of patients whose MD was $20 \pm 18.3 \%$.

Conclusions. Our results suggest that endogenous processes that lead to DNA damage and increased cell proliferation can contribute to the formation of MDT in the MG. These include all redox-dependent processes that occur in mitochondria and immune cells, which during their functioning could cause: superoxide radicals generation; increase of the activity of cells with NO-synthase activity; formation of lipid and protein peroxidation products; turninig on redox-dependent processes of AT degradation (activation of matrix metalloproteinase); increase of the metabolism of hormones by cytochrome P-450, for example, CYP 1A2, which metabolizes estradiol to 2-hydroxy and 4-hydroxy metabolites, the second of which is estrogenic and carcinogenic. Catechol estrogens can promote carcinogenesis by becoming a source of reactive oxygen species and entering the redox cycle (that is, repeated cycles of oxidation and reduction with the formation of 3, 4-semiquinones and 3, 4-quinones, which are highly reactive, can bind with DNA and create depurinating adducts that induce gene mutations and can lead to fibrous remodeling of adipose tissue and initiation of proliferation.

Key words: formation of mammographically dense breast tissue; 8-oxoguanine; superoxide radicals; nitric oxide; cytochrome P450; MMP-2; MMP-9.

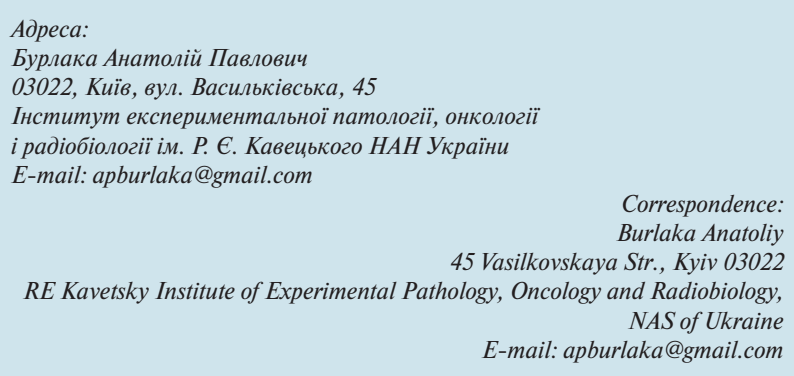

